\title{
Fungicide Selection and Nozzle Arrangement Impact Target Spot Control and Yield of Cotton
}

\author{
A. K. Hagan ${ }^{\dagger}$ and K. L. Bowen, Department of Entomology and Plant Pathology, Auburn University, Auburn, AL 36849; B. Miller, Brewton \\ Agricultural Research Unit, Brewton, AL 36427; S. Scott, Field Crops Unit, E. V. Smith Research Center, Shorter, AL 36075; and R. L. Nichols, \\ Cotton Incorporated, Cary, NC 27513
}

Accepted for publication 11 September 2017.

\begin{abstract}
Target spot is an emerging disease in cotton. Studies in southwest and central Alabama in 2013 and 2014 assessed Headline 2.09SC and Quadris 2.08SC efficacy against target spot for improving yield when applied in an over-the-top or drop-nozzle configuration to the susceptible Phytogen 499 WRF and partially resistant Deltapine 1252 B2RF varieties. At three location-years, onset occurred in late July and exceeded $50 \%$ defoliation by midSeptember; dry weather suppressed disease at the fourth location. Final defoliation was lower for the Headline drop than for the over-the-top nozzle arrangement and lower than Quadris regardless of nozzle arrangement. Despite higher defoliation of

Phytogen 499 WRF, both varieties had similar yields at two locations in 2013 and inconsistent yields in 2014. Relative area under the disease curve (relAUC) for defoliation differed by fungicide treatment across location-years. Fungicides increased yields at one location in 2013, with greater yields for the Headline and Quadris drop-nozzle treatments than the control. Across three location-years with $>50 \%$ defoliation, Headline drop-nozzle treatment improved Phytogen 499 WRF yield compared with no treatment. Despite better control, higher costs and maintenance issues will limit drop-nozzle use. Results show that a partially resistant variety is an effective target spot-management tool.
\end{abstract}

Target spot, caused by the fungus Corynespora cassiicola (Berk. \& M.A. Curtis) C.T. Wei, was first reported on cotton (Gossypium hirsutum L.) in the Mississippi Delta (Jones 1961). Subsequently, this disease reemerged in irrigated cotton in southwest Georgia in 2009 (Fulmer et al. 2012) and now is found in all cotton-producing states east of Texas (Butler et al. 2016; Conner et al. 2013; Faske 2013; Mehl et al. 2017; Price et al. 2015b). Target spot has also been reported in cotton in Brazil (Galbieri et al. 2014) and China (Wei et al. 2014).

Typically, lesions with alternating concentric rings of light- and dark-brown bands first appear on foliage at canopy closure one to three weeks after first bloom in the lower and mid-canopy, and with favorable wet conditions, often quickly spread upward through the plant canopy (Fig. 1A) (Conner et al. 2013). Leaves with multiple lesions prematurely senesce (Fig. 1B) (Conner et al. 2013). Defoliation may reach approximately $75 \%$ when 25 to $50 \%$ of bolls have opened on the susceptible variety Phytogen 499 WRF (Fig. 1C) (Conner et al. 2013). Reductions in lint yield but not fiber quality are associated with such damaging target-spot outbreaks (Hagan et al. 2015). In Alabama, estimated lint losses of 280 to $400 \mathrm{~kg} / \mathrm{ha}(250$ and $400 \mathrm{lb} / \mathrm{acre}$ ) were reported for the partially resistant Deltapine 1252 B2RF and susceptible Phytogen 499 WRF cotton varieties, respectively (Hagan et al. 2015). A negative correlation between target spot incited defoliation and cotton yield has also been reported by Mehl et al. (2017). Strong-growing cotton with yield potentials of $1680 \mathrm{~kg} / \mathrm{ha}(1500 \mathrm{lb} / \mathrm{acre})$ or greater are more vulnerable to target spot, particularly when irrigated and in close proximity to the Gulf Coast where frequent afternoon showers in July and August favor early onset and rapid disease development (Hagan 2014). Although in Alabama the risk of damaging disease outbreaks diminishes with

Corresponding author: A. K. Hagan; E-mail: haganak@auburn.edu

C 2017 The American Phytopathological Society increasing distance from the Gulf of Mexico (Hagan 2014), extensive leaf spotting and premature defoliation attributed to target spot have been observed in 2012 (Edmisten 2012) and 2013 (Walls et al. 2013) in the Mid-Atlantic and, in 2016, across the Mid-South production regions (Schultz et al. 2017).

Fungicides are useful for suppressing target spot-incited defoliation (Mehl et al. 2017), particularly under high disease pressure on the susceptible variety Phytogen 499 WRF (Hagan 2014). Yield protection from properly timed over-the-top broadcast applications of Headline 2.09SC (pyraclostrobin, BASF Ag Products, Research Triangle, NC) ranged up to 280 kilograms of lint per ha (250 lb/acre) at Alabama study sites (Hagan et al. 2016); this translates into a $\$ 388 /$ ha gain in farm-gate income at the current price of approximately $\$ 1.85 /$ ha of lint (Alabama Coop. Ext., Profit Profiles Report, 2 June 2017) after the \$74/ha fungicide costs are deducted. In contrast, yield gains from fungicide inputs are often negligible on a partially target spot-resistant variety, even under high disease pressure (Hagan et al. 2016).

Achieving efficacious and uniform pesticide deposition on leaf surfaces throughout the dense canopy of intensively managed cotton can be problematic. Nonuniform pesticide deposition may be influenced by canopy architecture and leaf density, fungicide formulation, weather, application pressure and volume, and nozzle type and arrangement (Ozkan et al. 2012; Sumner et al. 2000). In cotton, Sumner et al. (2000) noted that conventional hydraulic spray equipment provided better coverage of leaves within the canopy where the nozzles were directed, but failed to match the coverage uniformity achieved with air-assisted or electrostatic spray equipment. Superior beet armyworm (Spodoptera exiqua [Hübner]) control with the insecticide Capture 2EC-CAL, (bifenthrin, FMC Corporation, Philadelphia, PA) was obtained with upward trajectory drop nozzles compared with an over-the-top nozzle arrangement (Womac et al. 1992). As is the case with foliar diseases in soybean (Glycine 

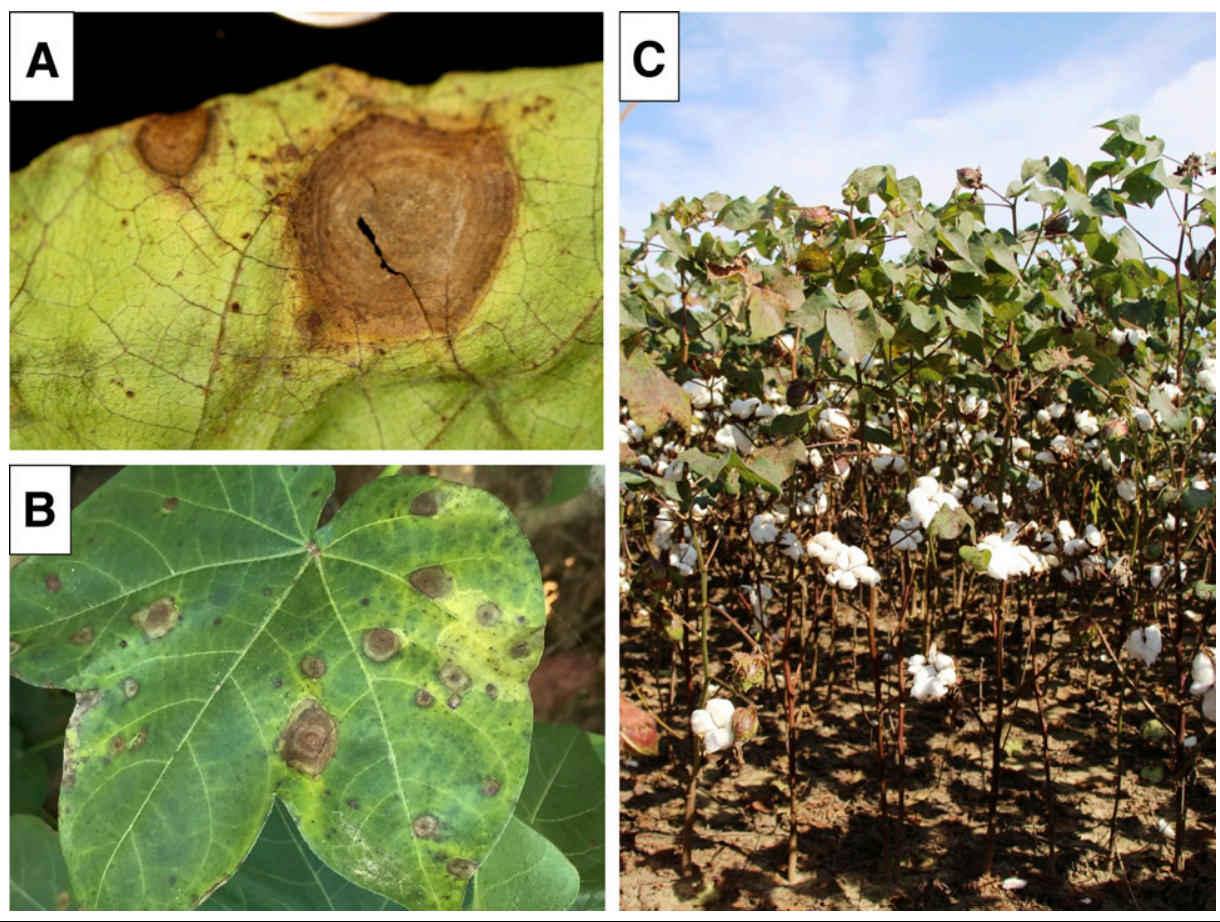

FIGURE 1

Target spot on cotton: (A) close-up of concentric light and dark brown rings in lesion; (B) multiple lesions on senescing leaf; and (C) $75 \%$ defoliation on Phytogen 499 WRF in early September.

max (L.) Merr.), including target spot, thorough coverage of upper surfaces of leaves in the lower and midcanopy, where target spot onset occurs (Conner et al. 2013), will be critical to delaying disease onset and intensification (Hanna et al. 2009). In the current study, a recommended rate of the strobilurin (Group 11) fungicides Headline 2.09SC and Quadris 2.08SC, applied twice with drop and over-the-top broadcast nozzle arrangements with a hydraulic sprayer, were compared for the control of target spot on a susceptible and partially resistant cotton variety at two Alabama locations in 2013 and 2014.

\section{Cotton Production, Disease Assessment, and Data Analysis}

Studies were conducted in 2013 and 2014 at the Brewton Agricultural Research Unit (BARU) located in Brewton, AL, $72 \mathrm{~km}$ northeast of Pensacola, FL, and the Field Crops Unit (FC) at the E. V. Smith Research Center, located in Milstead, AL, $40 \mathrm{~km}$ northeast of Montgomery, AL. The soil types at BARU and FC were, respectively, a Benndale sandy loam (coarse-loamy, siliceous, semiactive, thermic Typic Paleudults) and a Marvyn sandy loam (fine-loamy, kaolinitic, thermic Typic Kanhapludults). Soil fertility at both locations was adjusted according to the results of a soil fertility assay conducted by the Auburn University Soil Testing Laboratory. Weed and insect control was according to the recommendations of the Alabama Cooperative Extension System (Reed et al. 2017). Overhead irrigation was applied to plots as needed. A factorial set of treatments was arranged in a split-plot design with the target spot-susceptible Phytogen (PHY) $499 \mathrm{WRF}$ and partially resistant Deltapine (DP) 1252 B2RF varieties (Hagan 2014) as the main plots and five fungicide treatments as the split plot treatments. Individual experimental units consisted of four 9.1-m (30-ft) rows on $0.9 \mathrm{~m}$ (3-ft) centers in four replications. Cotton was sown at a rate of $6.7 \mathrm{seed} / \mathrm{m}$ ( 2 seed/ft) of row at BARU on 15 May 2013 and 8 May 2014 and at FC on 12 May 2013 and 13 May 2014. Fungicide treatments were: (i) a nontreated control; (ii) Headline 2.09SC at $164 \mathrm{~g}$ a.i./ha (9 $\mathrm{fl}$ oz/acre, pyraclostrobin, BASF Ag Products); or (iii) Quadris 2.08SC at $164 \mathrm{~g}$ a.i./ha (azoxystrobin, Syngenta Crop Protection, Greensboro, NC) broadcast 0.46 to $0.61 \mathrm{~m}$ ( 1.5 to $2 \mathrm{ft}$ ) over the top of the cotton canopy with TX-12 hollow cone nozzles (TeeJet Technologies, Glendale Heights, IL) on 0.5-m centers; as well as (iv) Headline 2.09SC at $164 \mathrm{~g}$ a.i./ha or (v) Quadris 2.08SC at $164 \mathrm{~g}$ a.i./ha applied with a dropnozzle arrangement that consisted of a single TX-12 hollow nozzle centered over the top of the row and one TX-12 hollow cone nozzle upward directed at $45^{\circ}$ on a $0.6-\mathrm{m}$ (20-in.) drop on each side of the row to deliver the fungicide into the cotton canopy. Fungicides were applied with a high-clearance sprayer calibrated to deliver spray volumes of 93 liters/ha at $69 \mathrm{kPa}$ and 187 liters/ha at $92 \mathrm{kPa}$ (10 and $20 \mathrm{gal} / \mathrm{acre}$ at 30 and $40 \mathrm{psi}$, respectively) at BARU and FC, respectively. Fungicide applications were scheduled on the 1st week and 3rd week of bloom, which corresponded to 18 July and 1 August 2013 and 11 July and 23 July 2014 at BARU; and 19 July and 5 August 2013 and 23 July and 8 August 2014 at FC.

Target spot intensity was assessed on 24 July, 15 August, 27 August, 10 September, and 20 September 2013 for BARU 13, and on 6 August, 12 August, 27 August, 31 August, 6 September, and 15 September 2013 for FC 13; on 16 July, 29 July, 12 August, 25 August, 11 September, and 18 September 2014 for BARU 14, and on 31 July, 14 August, 21 August, 29 August, 9 September, and 17 September 2014 for FC 14. Assessments used a 1-to-10 leaf spot scoring system where: 1 = no disease; 2 = very few lesions in canopy; 3 = few lesions noticed in lower and upper canopy; $4=$ some lesions seen and $<10 \%$ defoliation; $5=$ lesions noticeable and $<25 \%$ defoliation; $6=$ lesions numerous and $<50 \%$ defoliation; $7=$ lesions very numerous and $<75 \%$ defoliation; $8=$ numerous lesions on few remaining leaves and $<90 \%$ defoliation; $9=$ very few remaining leaves covered with lesions and $<95 \%$ defoliation; and 
$10=$ plants defoliated (Chiteka et al. 1988). Defoliation values were calculated using the following formula, modified from $\mathrm{Li}$ et al. 2012:

$$
\% \text { defoliation }=\frac{100}{1+e^{-\left[\frac{\text { disease intensityscore-6.0672 }}{0.7975}\right]}}
$$

Cotton was defoliated and prepared for harvest according to the recommendations of the Alabama Cooperative Extension System (Reed et al. 2017) and mechanically harvested at BARU on 13 October 2013 and 14 October 2014 and at FC on 6 October in 2013 and 2014.

Areas under disease progress curves (AUDPCs) were calculated for each plot using percent defoliation values (Shaner and Finney 1977). In order to compare AUDPCs across different years and study location, relative AUDPCs (relAUC) were determined by dividing AUDPC values by the number of days over which disease was monitored (i.e., 40, 49, 58, and 64 days, respectively, for FC 13, FC 14, BARU 13, and BARU 14). Final percent defoliation, relAUC, and seed cotton yield were the measured responses analyzed with a mixed model approach (PROC Glimmix, SAS 9.3 and 9.4, SAS Institute Inc., Cary, NC). Location-year, variety, and fungicide treatment were treated as fixed factors; random effects were block, block $\times$ location-year, and block $\times$ location-year $\times$ variety. Single-degree-of-freedom analyses between treatments within each variety were done to determine whether varietal yield responded similarly to fungicide treatments.

\section{Target Spot Defoliation as Influenced by Fungicide Treatment and Cotton Variety}

Year $\times$ location interactions were highly significant for relative area under the disease response curve (relAUC) and yield (Table 1), indicating variability among locations and years due to weather. However, final defoliation was significantly $(P<0.0001)$ affected by both variety and treatment, but not by location-year $(P=0.067)$ or any interactions $(P>0.10)$ (Table 1$)$. Headline applied with the drop nozzles allowed the lowest level of defoliation (Fig. 2A), while the same fungicide broadcast over-the-top allowed for significantly lower defoliation than Quadris, regardless of nozzle arrangement (Fig. 2A). When averaged across all location-years and cotton varieties, final defoliation levels for the Headline and Quadris with over-the-top and with drop-nozzle treatments were significantly lower compared with the nonfungicide treated control. The target spot-susceptible variety Phytogen 499 WRF sustained $45 \%$ final defoliation compared with $15 \%$ defoliation for the partially resistant variety Deltapine 1252 B2RF across the four location-years over the two-year study period (Fig. 2B). Absence of a significant variety $x$ treatment interaction illustrates that the fungicides acted similarly in reducing final defoliation on both varieties.

With the exception of FC 14 (Fig. 3D), disease onset in the nonfungicide controls occurred on both varieties in late July or early August (Fig. 3A-C). In all location-years, target-spot development in August and into September, as indicated by increasing premature defoliation, was often more rapid on the susceptible Phytogen 499 WRF than on the partially resistant Deltapine 1252 B2RF variety (Fig. 3A-D). By mid-August, defoliation levels for Phytogen 499 WRF approached $10 \%$ in the nonfungicide treated control at three of the four location-years-both BARU 13 and FC 13 along with BARU 14-while at FC 14, defoliation approaching 10\% was not seen until the beginning of September. The delay in premature defoliation observed at FC 14 (Fig. 2D) was likely associated with considerably lower rainfall and fewer rain days $(>0.64 \mathrm{~cm}(0.25 \mathrm{in}$.) rain in a 24-h period) during the 3 weeks prior to the observation of $10 \%$ defoliation (Fig. 4). Moisture conditions at FC 14 differed in particular to conditions at BARU 14 where greater rainfall totals and number of rain days were associated with accelerated disease development resulting in $70 \%$ final defoliation on Phytogen 499 WRF. In contrast to total rainfall and numbers of rain days, maximum and minimum temperatures were fairly consistent across location-years over the 3-week period prior to noticeable defoliation (Fig. 4). Final defoliation levels for Phytogen 499 WRF reached 55 to $80 \%$ by mid-September at FC 13, BARU 13, and BARU 14 compared with $40 \%$ or less at FC 14 . Lower premature defoliation was observed at nearly all disease assessment dates for Deltapine 1252 B2RF than for Phytogen 499 WRF in all locationyears. No more than $30 \%$ defoliation was observed at the final disease assessment at any of the four location-years for Deltapine 1252 B2RF.

Location-year, cotton variety, fungicide treatment, and the location-year $\times$ fungicide treatment, but not other interaction terms, had significant effects $(P \leq 0.05)$ on relAUC (Table 1). Season-long target spot-incited defoliation as indicated by relAUC values at FC 14 was lower compared with at FC 13 and BARU in both study years, while the FC 13 and BARU 13 and 14 relAUC values were comparable (Fig. 5A). As revealed by the significant location-year $\times$ treatment interaction, relAUC values differed by fungicide treatment across the four location-years. The Headline drop-nozzle plots had significantly lower relAUC than any other treatments, including Headline broadcast over-the-top, or Quadris regardless of nozzle arrangement, at two and three of the four location-years, respectively.

\begin{tabular}{|c|c|c|c|}
\hline \multirow[b]{3}{*}{ Source of variation } & $\begin{array}{l}\text { TABLE } 1 \\
\text { effects of location } \\
\text { ion, relAUC defoliat }\end{array}$ & $\begin{array}{l}\text { variety, and fungi } \\
\text { d seed yield }\end{array}$ & \multirow[b]{3}{*}{ Seed yield } \\
\hline & \multicolumn{2}{|c|}{ Target spot } & \\
\hline & Final defoliation (\%) & Defoliation relAUC $^{a}$ & \\
\hline Location-year & 0.067 & $<0.0001$ & $<0.0001$ \\
\hline Variety & $<0.0001$ & $<0.0001$ & 0.3827 \\
\hline Location-year $\times$ Fungicide treatment & 0.6681 & 0.0451 & 0.0286 \\
\hline Variety $\times$ Fungicide treatment & 0.3995 & 0.0804 & 0.7153 \\
\hline Location-year $\times$ Variety $\times$ Fungicide treatment & 0.1123 & 0.2722 & 0.3897 \\
\hline
\end{tabular}

${ }^{\mathrm{a}}$ relAUC $=$ Relative area under the disease progress curve for defoliation attributed to target spot. 

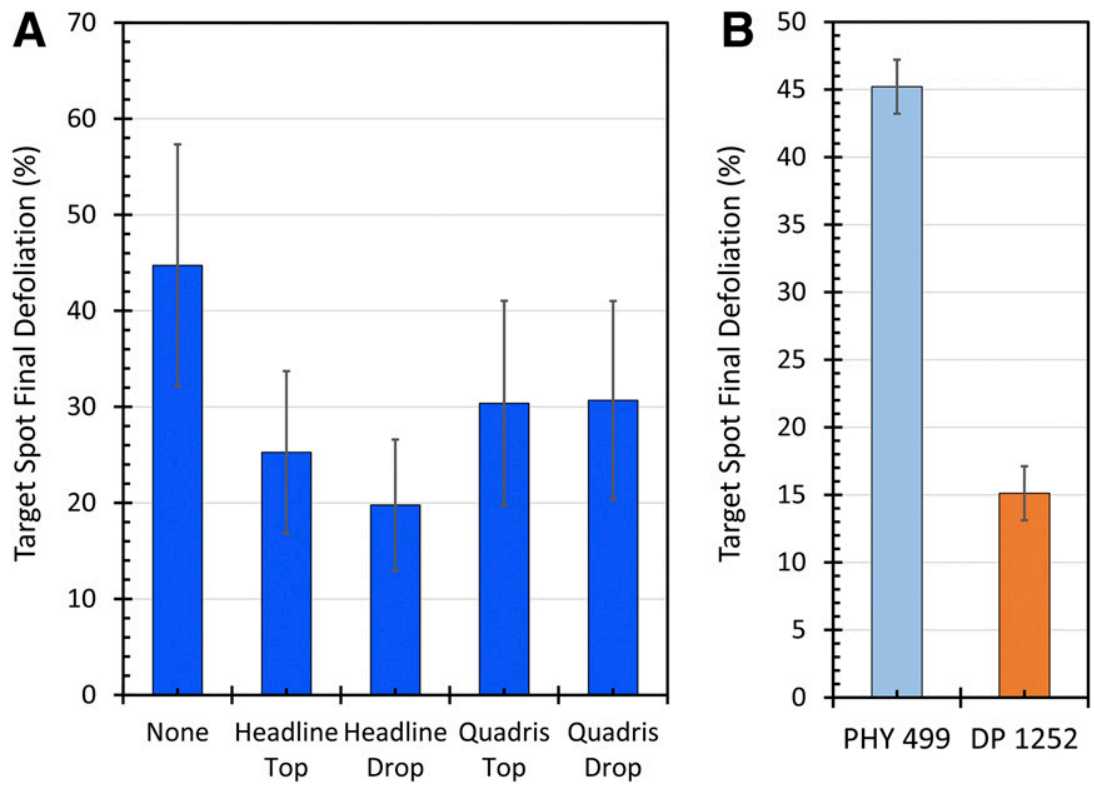

FIGURE 2

Final defoliation by (A) fungicide treatment and (B) cotton variety averaged over four location-years with Phytogen 499 WRF (PHY 499) and Deltapine 1252 B2RF (DP 1252). Lines on bars denote standard deviation of data.
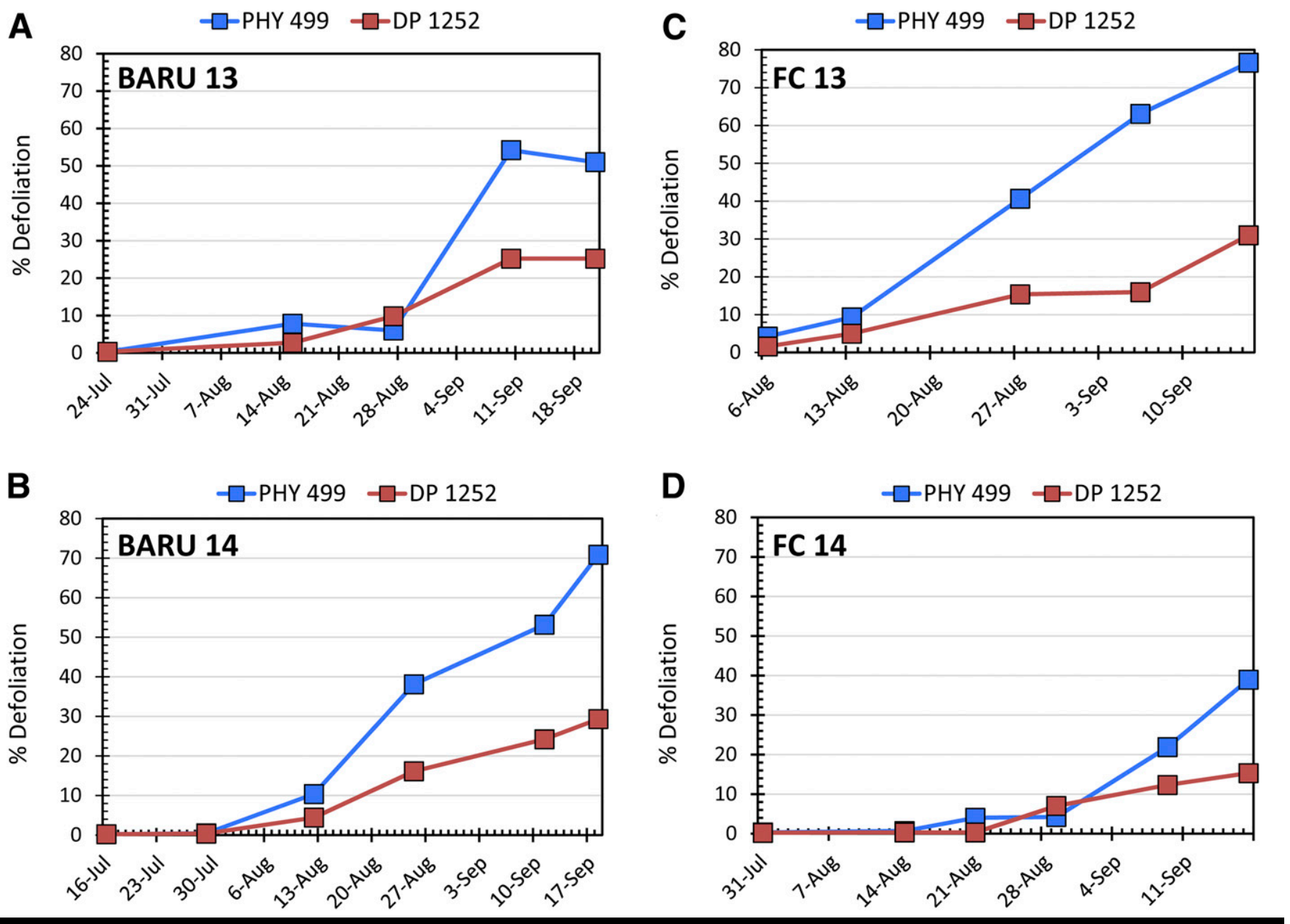

FIGURE 3

Defoliation (\%) by assessment date for the non-fungicide-treated controls for Phytogen 499 WRF (PHY 499) and Deltapine 1252 B2RF (DP 1252) at each locationyear. Data represents four replications of each variety. 
When compared with the nonfungicide treated control, relAUC values were reduced with Quadris in both nozzle arrangements in two of the four location-years. Nozzle arrangement did not impact Quadris relAUC values for any location-year. As indicated by a nonsignificant variety $\times$ fungicide interaction for relAUC, the response of both varieties to fungicide inputs was similar. Phytogen 499 WRF had a significantly higher mean relAUC defoliation value of 15.5 compared with the 6.5 recorded for Deltapine 1252 B2RF across all location-years (Fig. 5B).

Cotton seed yield was significantly $(P<0.03)$ influenced by location-year, location-year $\times$ variety, and location-year $\times$ treatment

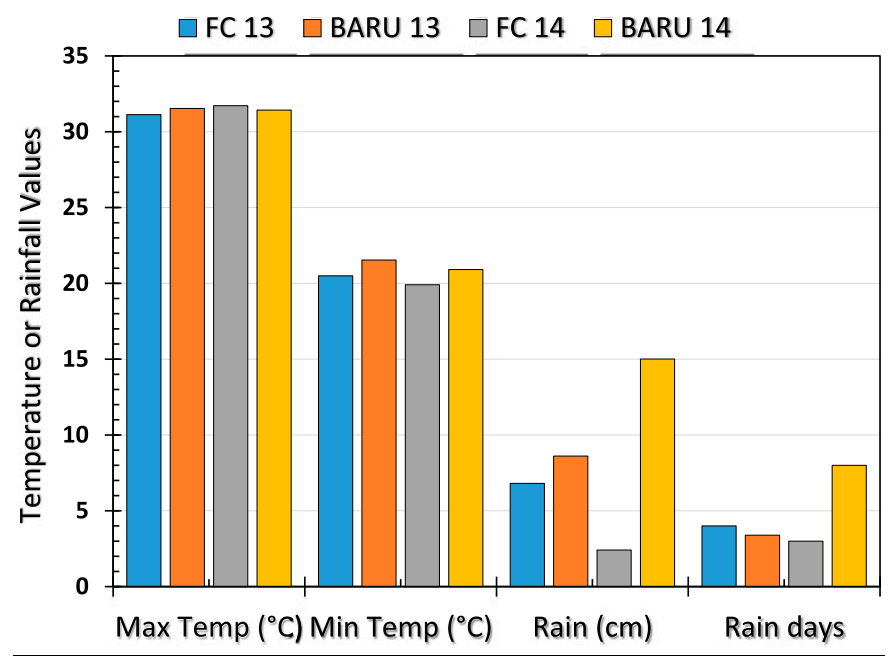

FIGURE 4

Average minimum and maximum temperatures along with total rainfall and number of rain events for 3 weeks prior to noticeable defoliation $(=10 \%)$ on Phytogen 499 WRF in the non-fungicide-treated controls: 6 August for FC 13; 31 July for BARU 13; 14 August for FC 14; and 30 July for BARU 14. interactions (Table 1). In 2013, the two varieties had similar yields at both study locations. Phytogen 499 WRF significantly outyielded Deltapine 1252 B2RF at FC 14, but significantly higher yields were obtained for Deltapine 1252 B2RF at BARU 14 (Fig. 6). Cotton at FC had significantly higher cotton seed yields than at BARU in 2013, but the reverse trend occurred in 2014. Effects of fungicide treatments on cotton seed yield were not consistent across location-years; e.g., the Headline and Quadris drop-nozzle applications had significantly greater yield than did nontreated plots at FC 13, while no significant differences in seed cotton yield were noted among any of the fungicide treatments regardless of nozzle arrangement and the nonfungicide treated control at FC 14 (Fig. 7). At BARU 14, significantly greater seed cotton yields were noted for Headline broadcast over-the-top than for the Quadris drop-nozzle treatment. Otherwise, cotton seed yields at BARU for the Headline and Quadris over-the-top and drop-nozzle treatments were similar and did not significantly differ from the nonfungicide treated control.

Single-degree-of-freedom comparisons between treatments for Phytogen 499 WRF, over the three location-years where $>50 \%$ defoliation was noted in mid-September, showed that the Headline drop-nozzle treatment significantly $(P=0.012)$ improved yield compared with no treatment (4589 and $4270 \mathrm{~kg} / \mathrm{ha}$ seed cotton per acre) or to either Quadris treatment $(P<0.001$ and $0.029 ; 4116$ (top) and 4270 (drop) $\mathrm{kg} / \mathrm{ha}$, respectively) (Table 2). Greater yield was also noted for the over-the-top Headline than Quadris treatment $(P<$ 0.016 ; 4458 versus $4116 \mathrm{~kg} / \mathrm{ha}$ lbs seed cotton per acre). No yield differences between fungicide treatments with Deltapine 1252 B2RF were recorded.

\section{Implications for Target Spot Control}

Target spot, which has been observed in the Southeast since 2009 and has sporadically been reported at damaging levels in the MidAtlantic and Mid-South areas of the southern U.S. cotton production region, has the potential to cause extensive premature

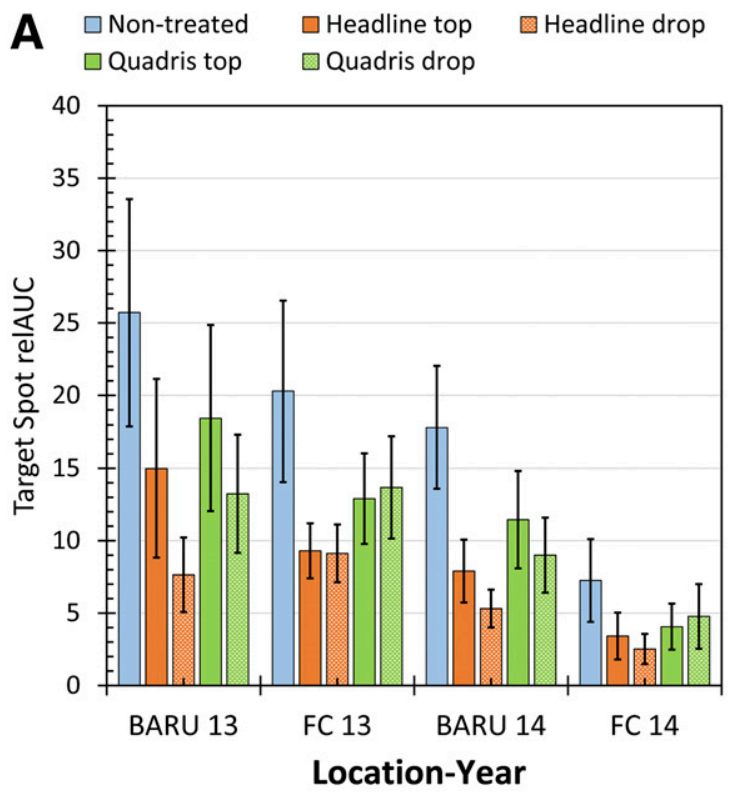

B

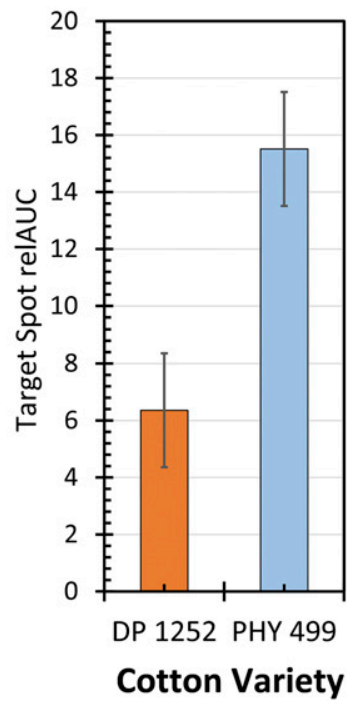

FIGURE 5

The relative area under the disease progress curve (relAUC), corrected for epidemic duration in each location-year, for defoliation for (A) fungicide treatments with data averaged over the two cotton varieties and 4 replications for each location-year and (B) cotton varieties Phytogen 499 WRF (PHY 499) and Deltapine 1252 B2RF (DP 1252) averaged over location-year and fungicide treatments. Lines on bars denote standard deviation of data. 


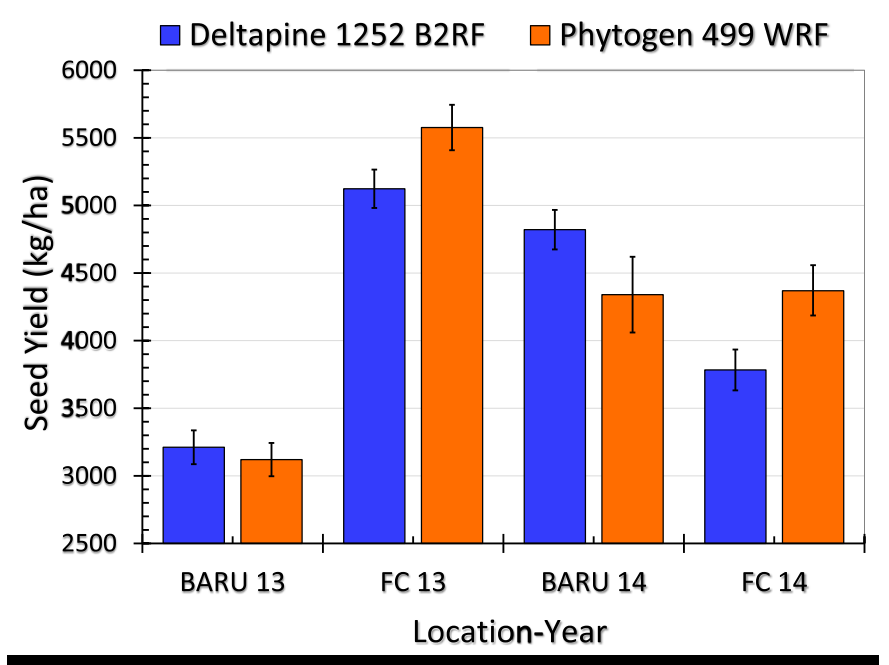

FIGURE 6

Seed yield for cotton varieties for each location-year. Lines on bars denote standard deviation of data.

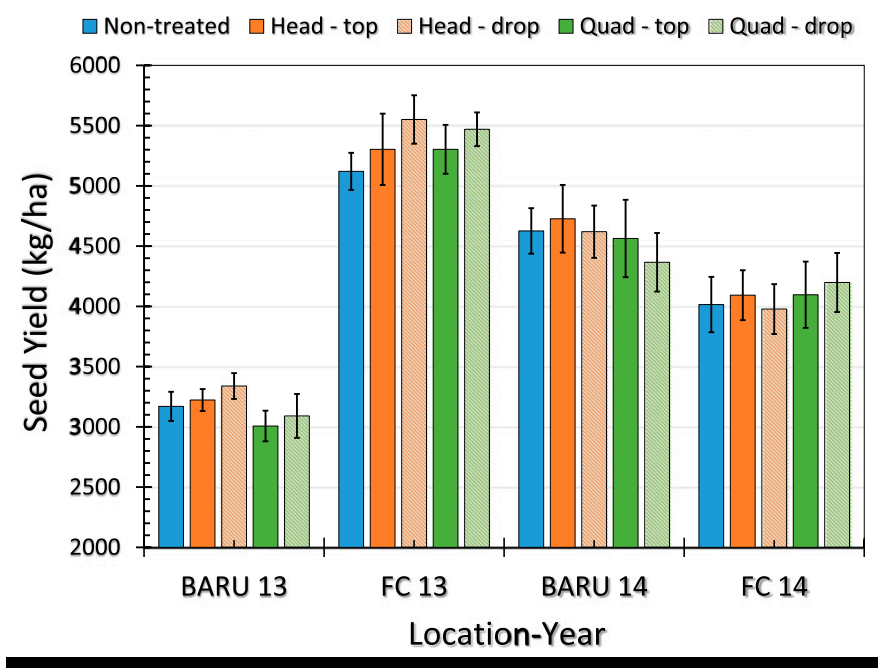

FIGURE 7

Average seed yield by fungicide treatment and location-year. Head - top = Headline broadcast; Head - drop = Headline drop nozzles; Quad - top = Quadris broadcast; and Quad - drop = Quadris drop nozzles. Data are averaged over two varieties and 4 replications. Lines on bars denote standard deviation of data. defoliation and sometimes significantly reduce yield. As has been previously noted by Hagan (2014), disease onset in the lower southeast - south Alabama and Georgia along with the Florida Panhandle, as indicated by the first appearance of lesions in the lower canopy - typically occurs in the last week of July or first week of August. Initiation of premature defoliation typically begins within one to two weeks of disease onset. Up to $80 \%$ premature defoliation may occur by early September. Total rainfall and number of rain events $(>0.64 \mathrm{~cm}(0.25 \mathrm{in}$.) in $24 \mathrm{~h})$ in July and early August are likely linked with early onset and rapid disease development, which was noticeably reduced on both cotton varieties under drier weather patterns at FC 14 as compared with FC 13 and BARU 14 where seasonal rainfall totals were higher. Previously, damaging target-spot outbreaks observed in mid-Atlantic (Edmisten 2012; Walls et al. 2013) and mid-South (Schultz et al. 2017) production regions followed extended periods of heavy rainfall or tropical weather events in early to midsummer.

Across all location-years, season-long defoliation, as indicated by relAUC values along with final defoliation levels, were generally greater with Quadris- than Headline-treated cotton. Better disease control was often recorded with the drop compared with the standard over-the-top broadcast nozzle arrangement with Headline. When compared with the nonfungicide treated control, Headline consistently reduced season-long defoliation ratings for target spot. Previously, Hagan et al. (2013) observed little difference in targetspot control with Quadris, Headline, or Twinline (pyraclostrobin + metconazole, BASF Ag Products) in field studies in southwest Alabama, while Price et al. (2015a) noted that the Headline-treated cotton sometimes suffered less target spot-incited defoliation compared with Quadris-treated cotton. The greater efficacy against target spot obtained with drop compared with the over-the top broadcast nozzle arrangement, particularly with Headline, can likely be attributed to improved coverage of the leaves in the lower and midcanopy (Sumner et al. 2000), which is the site for disease onset and initial premature defoliation. Enhanced control of foliage feeding insect pests in cotton (Womac et al. 1992), as well as improved foliar disease control in soybean (Hanna et al. 2009), has been obtained with drop versus over-the-top nozzle arrangements.

Drop nozzles are not a panacea for improving target-spot control in cotton. Despite the potential for enhanced insect and disease control in cotton (Womac et al. 1992), drops are rarely employed, particularly on large towed or self-propelled sprayers. Drops are easily dislodged from the spray boom, and the added cost for replacement parts and labor costs along with equipment down-time are unacceptable, nor are drops routinely used to apply other pesticides to cotton. Despite superior target-spot control, particularly with

\begin{tabular}{|c|c|c|c|c|c|c|}
\hline \multirow[b]{3}{*}{ Variety } & \multicolumn{6}{|c|}{ 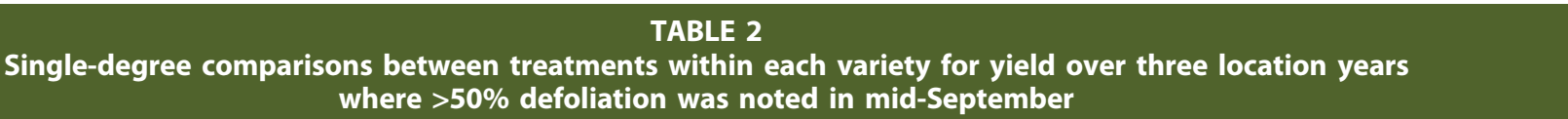 } \\
\hline & \multirow[b]{2}{*}{ Fungicide treatment } & \multirow[b]{2}{*}{ Seed yield (kg/ha) } & Headline - top & Headline - drop & Quadris - top & Quadris - drop \\
\hline & & & \multicolumn{4}{|c|}{$P$-values } \\
\hline \multirow[t]{3}{*}{ DP 1252} & Nontreated & 4344 & 0.273 & 0.532 & 0.831 & 0.857 \\
\hline & Headline - top & 4470 & $\ldots$ & 0.623 & 0.374 & 0.375 \\
\hline & Quadris - drop & 4347 & $\ldots$ & $\ldots$ & $\ldots$ & $\ldots$ \\
\hline \multirow[t]{5}{*}{ PHY 499} & Nontreated & 4269 & 0.117 & 0.012 & 0.385 & 0.718 \\
\hline & Headline - top & 4458 & $\ldots$ & 0.322 & 0.016 & 0.226 \\
\hline & Headline - drop & 4587 & $\ldots$ & $\ldots$ & 0.001 & 0.029 \\
\hline & Quadris - top & 4116 & $\ldots$ & $\ldots$ & $\ldots$ & 0.220 \\
\hline & Quadris - drop & 4269 & $\ldots$ & $\ldots$ & $\ldots$ & $\ldots$ \\
\hline
\end{tabular}


Headline, no yield advantage was attributed to the drop compared with conventional over-the-top nozzle arrangement.

While Headline, and to a lesser extent Quadris, were effective in reducing season-long and final target spot-incited defoliation, significant yield gains, over the two varieties and compared with the nonfungicide treated control, were noted with drop-nozzle applications of the above fungicides only at FC 13 . Concurrent with this study, Price et al. (2015b) in Louisiana, Hagan et al. (2013) in Alabama, and Walls et al. (2013) in Georgia and Virginia also failed to consistently link target-spot control with the these same fungicides to significant yield gains. Mehl et al. (2017) also reported inconsistent yield gains from the Headline, Quadris, and more efficacious Priaxor Xemium Brand Fungicide (fluxapyroxad + pyraclostrobin, BASF) on Phytogen 499 WRF and Deltapine 1137 $\mathrm{B} 2 \mathrm{RF}$ varieties despite reductions in premature defoliation across multiple study sites in six states over the three-year study period. In Alabama, however, target-spot intensity and yield loss risk declines on both susceptible and partially resistant varieties with increasing distance from the Gulf of Mexico (Hagan 2014), which could explain some inconsistencies. However, comparisons among treatments to Phytogen 499 WRF, over the four location-years of the current study, showed that Headline applied with drop nozzles improved yield compared with no treatment. Based on the results of this and other Alabama studies (Hagan et al. 2013, 2015, 2016), significant fungicide-related yield gains are typically recorded when defoliation in mid-September exceeds 60 to $70 \%$, particularly on target spot-susceptible varieties.

Partially resistant varieties are a critical component for managing target spot in cotton. As noted here, relAUC and final defoliation levels are lower for Deltapine 1252 B2RF than Phytogen 499 WRF. Yields were similar to or higher for the former than latter variety for three of four location-years. Greater yields for Deltapine 1252 B2RF at BARU 14 may be attributed to superior adaptability to the Southwest Alabama production region or reduced target spot-incited yield loss when compared with the susceptible Phytogen 499 WRF, which produced greater yields under reduced disease pressure at FC 14. With the exception of Phytogen 499 WRF, the majority of other mid- and full-season flex cotton varieties marketed by Deltapine, Phytogen, and Stoneville appear to have partial resistance to target spot (Hagan et al. 2016; Hagan et al. 2017), and they currently dominate the southeastern cotton seed market (USDA, 2016). It must be noted that the majority of newly released cotton varieties, with phenoxy herbicide tolerance and triple stacked Bt traits, have not been screened for their reaction to target spot or response to fungicide inputs; the varieties evaluated in this and other recent field studies (Hagan 2014; Hagan et al. 2016) will be discontinued.

As has been noted here and in subsequent Alabama studies (Hagan et al. 2016, 2017; Mehl et al. 2017), reduced premature defoliation on a variety with partial target-spot resistance does not necessarily translate into greater yields. However, cropping a partially resistant variety reduces the risk of damaging target-spot outbreaks as well as the need for costly fungicide inputs to those areas in close proximity to the Gulf of Mexico where disease pressure is high nearly every year due to favorable summer weather patterns. For producers in Central and North Alabama who often face minimal target-spot pressure, adapted varieties with partial resistance should be sufficient, particularly in rain fed fields, to minimize target-spot development and negate the need for fungicide inputs except in those years with unusually wet midsummer weather patterns.

\section{Acknowledgments}

Funding for this project was provided by the Alabama Agricultural Experiment Station, and grants from USDA NIFA Crop Pest and Pest
Management Program, the Alabama Cotton Commission, and a cooperative research agreement with Cotton Incorporated.

\section{Literature Cited}

Butler, S., Young-Kelly, H., Raper, T., Cochran, A., and Jordan, J. 2016. First report of target spot caused by Corynespora cassiicola on cotton in Tennessee. Plant Dis. 100:535.

Chiteka, Z. A., Gorbet, D. W., Shokes, F. M., Kucharek, T. A., and Knauft, D. A. 1988. Components of resistance to late leaf spot in peanut. I. Levels of variability-implications for selection. Peanut Sci. 15:25-30. http://www. peanutscience.com/doi/pdf/10.3146/i0095-3679-15-1-8

Conner, K., Hagan, A. K., and Zhang, L. 2013. First Report of Corynespora cassiicola-incited target spot on cotton in Alabama. Plant Dis. 97:1379.

Edmisten, K. 2012. Target leaf spot found in North Carolina cotton. Southeast Farm Press. 23 August 2012. Online publication. http://southeastfarmpress. com/cotton/target-leaf-spot-found-north-carolina-cotton.

Faske, T. 2013. Cotton disease alert: Corynespora leaf spot has been detected in Arkansas. Arkansas Row Crops. 26 August 2013. Online publication. http:// www.arkansas-crops.com/2013/08/26/cotton-disease-alert-corynespora-leafspot-has-been-detected-in-arkansas/

Fulmer, A. M., Walls, J. T., Dutta, B., Parkunan, V., Brock, J., and Kemerait, R. C., Jr. 2012. First report of target spot caused by Corynespora cassiicola on cotton in Georgia. Plant Dis. 96:1066.

Galbieri, R., Araújo, D. C. E. B., Kobayashi, L., Girotto, L., Matos, J. N., Marangoni, M. S., Alemida, W. P., and Mehta, Y. R. 2014. Corynespora leaf blight of cotton in Brazil and its management. Am. J. Plant Sci. 5: 3805-3811.

Hagan, A. K. 2014. Target spot management options in Alabama. Pages 45-48 in: Proc. Beltwide Cotton Conf. Natl. Cotton Counc. Am., Memphis, TN.

Hagan, A. K., Bowen, K. L., Burch, K., Pegues, M., Jones, J., and Scott, S. 2017. Impact of planting date and seeding rate on the severity of target spot in cotton. Pages 224-232 in: Proc. Beltwide Cotton Conf. Natl. Cotton Counc. Am., Memphis, TN.

Hagan, A. K., Bowen, K. L., Pegues, M., and Jones, J. 2015. Relationship between target spot intensity and seed cotton yield. Phytopathology 105: $\mathrm{S} 2.4$.

Hagan, A. K., Burch, K., and Miller, H. B. 2016. Yield and response of fullseason flex cotton varieties to target spot in Alabama. Pages 897-907 in: Proc. Beltwide Cotton Conf. Natl. Cotton Counc. Am., Memphis, TN.

Hagan, A. K., Pegues, M., and Jones, J. 2013. Efficacy of registered and candidate fungicides against target spot (Corynespora leaf spot) compared. Pages 20-24 in: Proc. Beltwide Cotton Conf. Natl. Cotton Counc. Am., Memphis, TN.

Hanna, H. M., Robertson, A. E., Carlton, W. M., and Wolf, R. E. 2009. Nozzle and carrier application effects on control of soybean leaf spot diseases. Appl. Eng. Agric. 25:5-13.

Jones, J. P. 1961. A leaf spot of cotton caused by Corynespora cassiicola. Phytopathology 51:305.

Li, Y., Culbreath, A. K., Chen, C. Y., Knapp, S. J., Holbrook, C. C., and Guo, B. 2012. Variability in field response of peanut genotypes from the U.S. and China to tomato spotted wilt virus and leaf spots. Peanut Sci. 39:30-37.

Mehl, H., Dufault, N., Mulvaney, M., Hagan, A. K., Kelly, H., Kemerait, R., Price, P., Allen, T., Lawrence, K., and Nichols, R. 2017. Multi-year regional evaluation of one and two applications of registered and experimental fungicides for the management of target spot on two cotton varieties. Pages 222-223 in: Proc. Beltwide Cotton Conf. Natl. Cotton Counc. Am., Memphis, TN.

Ozkan, H. E., Paul, P., Derksen, R. C., and Zhu, H. 2012. Influence of application equipment on deposition of spray droplets in wheat canopy. Int. Advances in Pesticide Appl.-Aspects of Applied Biol. 114:317-324. https:// naldc.nal.usda.gov/download/54119/PDF

Price, P., Purvis, M. A., Pruitt, H., and Bartleson, J. 2015a. Effect of fungicide and application timing on target spot in Louisiana. Page 215-219 in: Proc. Beltwide Cotton Conf. Natl. Cotton Counc. Am., Memphis, TN.

Price, P., Singh, R., and Fromme, D. 2015b. First report of target spot caused by Corynespora cassiicola in Louisiana cotton. Plant Health Prog. 16:223-224.

Reed, T., Jacobson, A., Smith, R., Freeman, B., Hagan, A. K., Tredaway, J. A., and Monks, D. 2017. Cotton: Insect, disease, nematode, and weed control recommendations for 2017. Pub. No. IPM-0415, Alabama Coop. Ext. System. http://www.aces.edu/pubs/docs/I/IPM-0415/IPM-0415.pdf

Schultz, J., Bane, R., Roberts, J., Rhodes, A., Clark, J., and Westberg, D. 2017. Target spot epidemic in the north Delta: 2016, observations and key learnings. Page 242 in: Proc. Beltwide Cotton Conf. Natl. Cotton Counc. Am., Memphis, TN

Shaner, G., and Finney, R. E. 1977. The effect of nitrogen fertilization on the expression of slow-mildewing resistance in wheat. Phytopathology 67:1051-1056. 
Sumner, H. R., Herzog, G. A., Sumner, P. E., Bader, M., and Mullinix, B. O. 2000. Chemical application equipment for improved deposition in cotton. Cotton Sci. 4:19-27.

USDA. 2016. Cotton varieties planted, 2016 crop. Publ. No. mp_cn833. Cotton and Tobacco Program, USDA-Agricultural Marketing Service, Memphis, TN. http://usda.mannlib.cornell.edu/usda/ams/CNAVAR.pdf

Walls, J. T., Fulmer, A. M., Kemerait, R. C., Jr., Sanders, F. H., Perry, C., Newell, S., Newsom, L., Byrne, R. J., and Phipps, P. 2013. Impact of application timing of fungicides on the management of target spot. Page 12-19 in: Proc. Beltwide Cotton Conf. Natl. Cotton Counc. Am., Memphis, TN.

Wei, Y.-X., Zhang, H., Pu, J.-J., and Liu, X.-M. 2014. First report of target spot caused by Corynespora cassiicola in China. Plant Dis. 98:1006-1007.

Womac, A. R., Mulrooney, J. E., and Scott, W. P. 1992. Characteristics of air-assisted and drop-nozzle sprays in cotton. Trans. ASAE 35: 1369-1376. 